\title{
Lectins and Their Roles in Pests Control
}

\author{
J. Karimi ${ }^{1}$, M. Allahyari ${ }^{2}$ and A. R. Bandani ${ }^{3}$ \\ ${ }^{1}$ Plant Protection Department, Shahed University, Tehran, \\ ${ }^{2}$ Department of Plan Pests and Disease, Fars Agriculture \\ and Natural Resources Research Center, Shiraz, \\ ${ }^{3}$ Plant Protection Department, University of Tehran, Karaj, \\ Iran
}

\section{Introduction}

Losses in agricultural production due to pests and diseases have been estimated at $37 \%$ of total production worldwide, with $13 \%$ due to insect pests (Gatehouse, 1998). Over the last decades, the use of chemical compounds, such as pesticides has been rapidly increased. Thus, the harmful effects of insecticides on non target organisms and environment are well documented in order to limit their use. This fact justifies the necessity for research and development of alternative approach to balance agricultural, environmental and health issues, in crop protection. The new alternative to chemical compound was the use of bacteria, Bacillus thuringiensis (Berliner) (Bt) and several strains of this bacteria were introduced as biopesticide to a wide range of insect pests. In recent years, due to increasing resistance of some insect pests to $\mathrm{Bt}$, new approaches including the use of entomotoxic proteins has been proposed for the insect pest control (Aronson, 1994; Ferre and Rie, 2002; Janmaat and Myers, 2003).

To date, there are many proteins with insecticidal properties that have been identified. These are lectins, ribosome-inactivating proteins, protease inhibitors, a-amylase inhibitors, arcelin, canatoxin-like protein, ureases and chitinases. Among them, lectins, ribosome-inactivating proteins, a-amylase inhibitors and protease inhibitors, have shown greater potential effects on biological parameters to a wide range of important insect pests and for exploitation in transgenic-based pest control strategies (Carlini et al., 2002; Vasconcelos et al., 2004). Other classes of plant secondary compounds which have been implicated in protection against insect attack include the steroids, terpenoids, glucosinolates, cyanogenic glycosides, rotenoids, flavanoids, phenolics, saponins and nonprotein amino acids (Gatehouse, 1991). Production of some of these compounds imposes a demonstrable metabolic cost on the plants, indicated by a reduced fitness in the absence of predation; this suggests that their production in the plant is a selective response to insect feeding (Baldwin, 1990).

Therefore, the new efficient strategy to control insect pest has been based on toxic proteins such as lectins. Thus, the focus of the current chapter is to introduce and highlight insecticidal activity of some important lectins from plants and especially fungal lectins. 


\section{General role and behavior of lectins}

They are one of the most important secondary metabolites in plants which are used as a defense tool against pathogens which attack plants. According to Peumans \& Van Damme (1995) definition "Lectins are a class of proteins of non-immune origin that possess at least one non-catalytic domain that specifically and reversibly bind to mono-or oligosaccharides". They are similar to antibodies in their ability to agglutinate red blood cells; however lectnis are not the product of immune system. They may bind to a soluble carbohydrate or to a carbohydrate moiety that is a part of a glycoprotein or glycolipid. These glycoproteins or glycolipid are multivalent and possess more than one sugar binding site (Lis \& Sharon, 1998, Rudiger et al., 2001; Van Damme et al., 1998; Goldstein and Poretz, 1986). "Based on the overall domain architecture of plant lectins, four major groups can be distinguished: merolectins, hololectins, chimerolectins and superlectins" (Van Damme et al., 1998).

They were first discovered more than 100 years ago by Stillmark (1888) and they are extensively distributed in nature and several hundred of these molecules have been isolated from different organisms (Peumans \& Van Damme, 1995; Van Dam et al., 1998). They encompass different members that are diverse in their sequences, structures, binding site architectures, carbohydrate affinities and specificities as well as their larger biological roles and potential applications (Peumans \& Van Damme, 1995; Van Dam et al., 1998; Chandra et al., 2006). Different roles and functions have been ascribed to lectins. The principal function of lectins are to act as recognition molecules within the immune system, storage proteins, cell surface adhesion and they have been implicated in defence mechanisms of plants against invading pathogens and pests (Peumans \& Van Damme, 1995; Van Dam et al., 1998; Rudiger \& Gabius, 2001; Trigueros et al., 2003).

\section{Principle of entomotoxic lectins}

Various lectins from different sources have already been found to be toxic towards important members of insect orders, including Lepidoptera (Czapla \& Lang, 1990), Coleoptera (Gatehouse et al., 1984; Czapla \& Lang, 1990) and Homoptera (Powell et al., 1993; Sauvion et al., 1996). The harmful effects of lectins on biological parameters of insects are larval weight decrease, mortality, feeding inhibition, delays in total developmental duration, adult emergence and fecundity on the first and second generation (Powell et al., 1993; Habibi et al., 1993). Also insecticidal activity of some lectins against many important pest insects has been well documented showing their ability to be used as bio-pesticides (Gatehouse et al., 1995; Powell, 2001; Carlini \& Grossi-de-Sa', 2002) (Table 1). Currently, the promising methods for plant resistance against insects attack is exploiting the potential toxicity of plant and the other organisms including fungal lectins towards some of the economically insect pests (Foissac et al., 2000; Carlini et al., 2002; Trigueros et al., 2003; Sauvion et al., 2004, karimi et al., 2007). Therefore our more attention on the ability of lectis as natural product of plants will be one of the good alternatives to chemical compound to control of insect pests.

\section{Plant lectins}

Lectins are a group of proteins that are found in plants and they discourage predation by being harmful to various types of insects and animals that eat plants. During the last two 


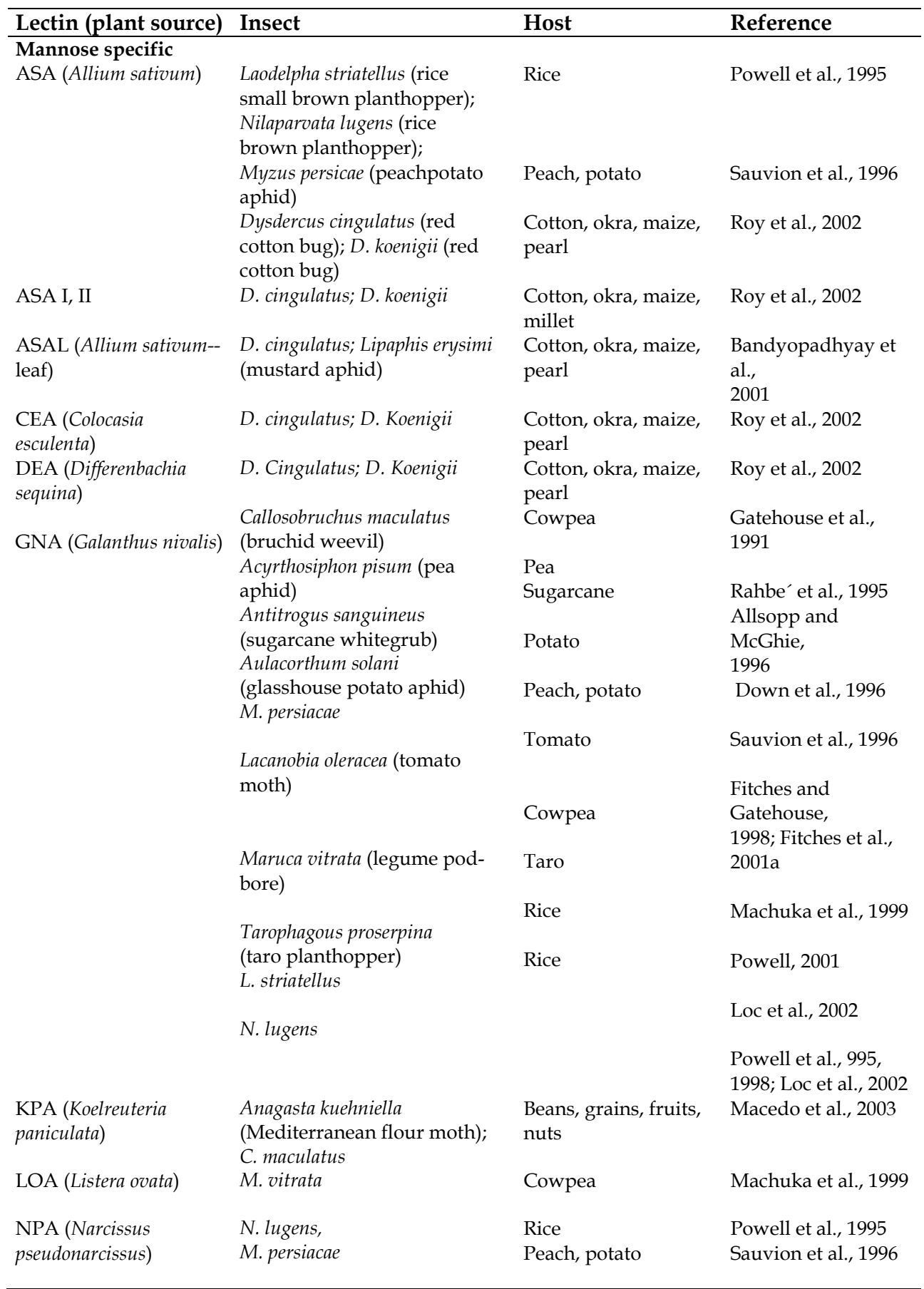




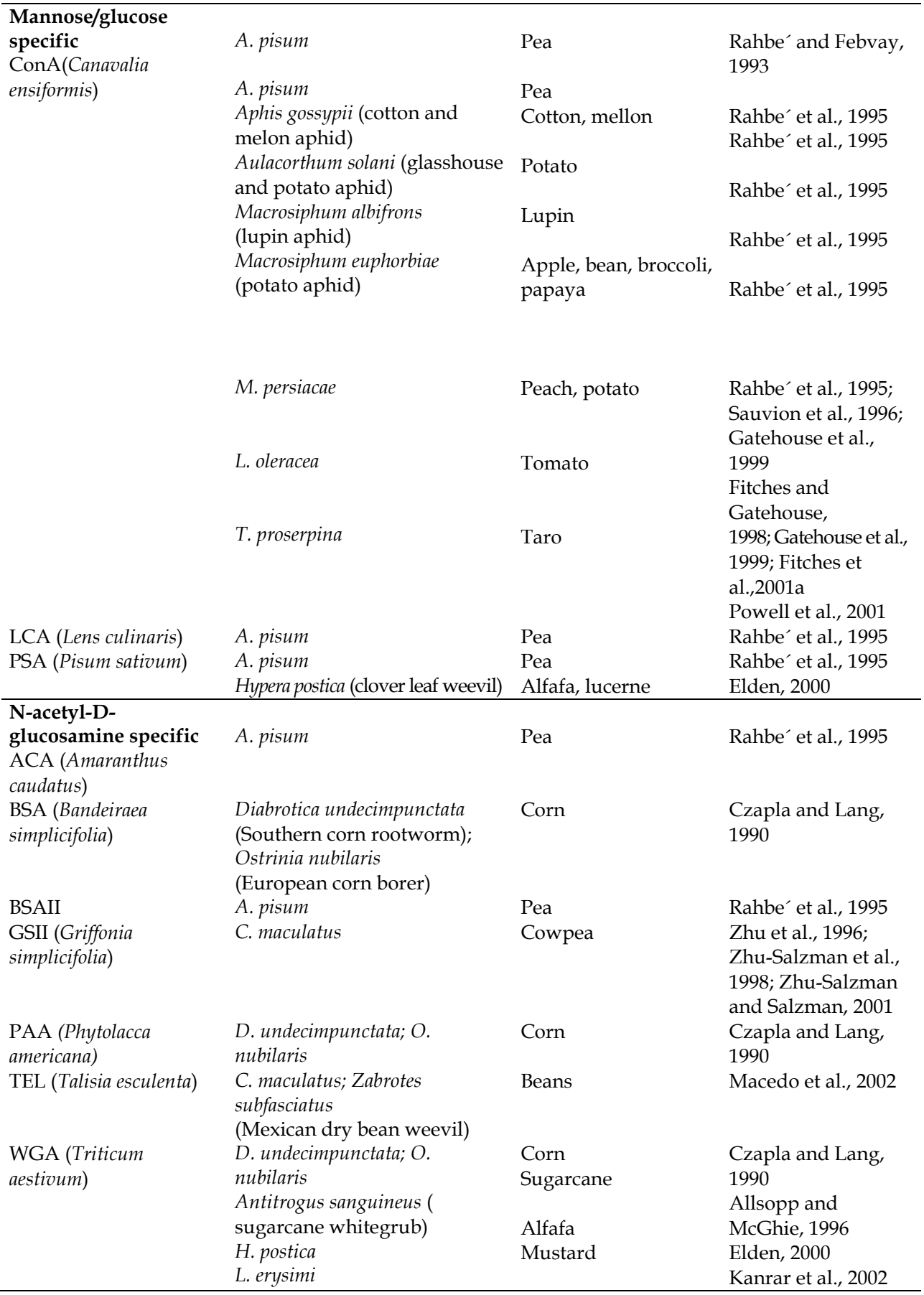




\begin{tabular}{|c|c|c|c|}
\hline \multicolumn{4}{|l|}{ Galactose specific } \\
\hline $\begin{array}{l}\text { AHA (Artocarpus } \\
\text { hirsuta) }\end{array}$ & $\begin{array}{l}\text { Tribolium castaneum (red flour } \\
\text { beetle) }\end{array}$ & $\begin{array}{l}\text { Large number of } \\
\text { grains }\end{array}$ & Gurjar et al., 2000 \\
\hline $\begin{array}{l}\text { AIA (Artocarpus } \\
\text { integrifolia) }\end{array}$ & $\begin{array}{l}\text { D. undecimpunctata; } O \text {. } \\
\text { nubilaris }\end{array}$ & Corn & $\begin{array}{l}\text { Czapla and Lang, } \\
1990\end{array}$ \\
\hline $\begin{array}{l}\text { GHA (Glechoma } \\
\text { hederacea - leaf) }\end{array}$ & $\begin{array}{l}\text { Leptinotorsa decemlineata } \\
\text { (colorado } \\
\text { potato beetle) }\end{array}$ & Potato & Wang et al., 2003 \\
\hline $\begin{array}{l}\text { RCA120 (Ricinus } \\
\text { communis) }\end{array}$ & $\begin{array}{l}\text { D. undecimpunctata; } O \text {. } \\
\text { nubilaris }\end{array}$ & Corn & $\begin{array}{l}\text { Czapla and Lang, } \\
1990\end{array}$ \\
\hline \multirow[t]{3}{*}{$\begin{array}{l}\text { YBA (Sphenostylis } \\
\text { stenocarpa) }\end{array}$} & $\begin{array}{l}\text { Clavigralla tomentosicollis } \\
\text { (coreid bug) }\end{array}$ & & $\begin{array}{l}\text { Okeola and } \\
\text { Machuka, }\end{array}$ \\
\hline & C. maculatus; M. vitrata & Cowpea & 2001 \\
\hline & & & Machuka et al., 2000 \\
\hline $\begin{array}{l}\text { N-acetyl-D- } \\
\text { galactosamine specific } \\
\text { ACA (Amaranthus } \\
\text { caudatus) }\end{array}$ & A. pisum & Pea & Rahbe' et al., 1995 \\
\hline $\begin{array}{l}\text { BFA (Brassica } \\
\text { fructiculosa) }\end{array}$ & $\begin{array}{l}\text { Brevicoryne brassicae (cabbage } \\
\text { aphid) }\end{array}$ & $\begin{array}{l}\text { Broccoli, } \\
\text { Brusselessprous, } \\
\text { cauliflower, head } \\
\text { cabbage }\end{array}$ & Cole, 1994 \\
\hline BPA (Bauhinia purpurea) & $\begin{array}{l}\text { D. undecimpunctata; } O \text {. } \\
\text { nubilaris }\end{array}$ & Corn & $\begin{array}{l}\text { Czapla and Lang, } \\
1990\end{array}$ \\
\hline CFA (Codium fragile) & $\begin{array}{l}\text { D. undecimpunctata; } O \text {. } \\
\text { nubilaris }\end{array}$ & Corn & $\begin{array}{l}\text { Czapla and Lang, } \\
1990\end{array}$ \\
\hline EHA (Eranthis hyemalis) & D. undecimpunctata & Corn & Kumar et al., 1993 \\
\hline MPA (Maclura pomifera) & $\begin{array}{l}\text { D. undecimpunctata; } O \text {. } \\
\text { nubilaris }\end{array}$ & Corn & $\begin{array}{l}\text { Czapla and Lang, } \\
1990\end{array}$ \\
\hline PTA (Psophocarpus & C. maculatus & Cowpea & Gatehouse et al., \\
\hline tetragonolobus) & N. lugens & Rice & 1991 \\
\hline & & & Powell, 2001 \\
\hline $\begin{array}{l}\text { SNA-II (Sambucus } \\
\text { nigra) }\end{array}$ & A. pisum & Pea & Rahbe' et al., 1995 \\
\hline VVA & $\begin{array}{l}\text { D. undecimpunctata; } O \text {. } \\
\text { nubilaris }\end{array}$ & Corn & $\begin{array}{l}\text { Czapla and Lang, } \\
1990\end{array}$ \\
\hline Complexb & & & \\
\hline $\begin{array}{l}\text { PHA (Phaseolus } \\
\text { vulgaris) }\end{array}$ & $\begin{array}{l}\text { L. hesperus (Western tarnished } \\
\text { plant bug) }\end{array}$ & $\begin{array}{l}\text { Cotton, alfafa, } \\
\text { legumes }\end{array}$ & Habibi et al., 2000 \\
\hline
\end{tabular}

a Sugar specificity is represented by the best monosaccharide inhibitor.

b Complex carbohydrate structure bearing terminal galactose residues (Goldstein and Poretz, 1986).

Table 1. Plant lectins with oral toxicity to insects (Adapted from Vasconcelos et al., 2004)

decades, important progress has been made in the study of the activity of plant lectins against pathogens, nematodes and especially insect pests (Ma et al., 2010; Peumans and Van Damme, 1995; Vasconcelos and Oliveira, 2004). The best-characterized family of plants lectins are Fabaceae, Poaceae and Solanaceae; especially some of leguminous seeds have a remarkable amount of lectin. Different food crops such as tomato, wheat, rice, potato, soybean and bean contain lectins. The great majority of the plant lectins are present in seed cotyledons but a lot of them are also found in the protein bodies such as roots, leaf, stems, rhizomes, bark, bulbs, tubers, corms, fruits, flowers, ovaries, phloem sap, latex, nodule and 
even in nectar (Van Damme et al., 1998). Plant lectins function as storage proteins and they have been implicated in defence mechanisms against phytophagus insects (Powell et al., 1993; Peumans \& Van Damme, 1995; Van Damme et al., 1998; Rudiger \& Gabius, 2001; Gatehouse et al., 1995; Powell, 2001; Carlini \& Grossi-de-Sa', 2002; karimi et al., 2010). Various plants lectins have already been found to be toxic towards important members of insect orders, including Coleoptera (Gatehouse et al., 1984), Lepidoptera (Czapla \& Lang, 1990) and Homoptera (Powell et al., 1993; Sauvion et al., 1996) (Table 1). The first lectin to be purified on a large scale and was available on a commercial basis was Concanavalin A; which is now the most well- known lectin to control of some pest insects (Fig. 1A). Now a wide range of plant lectins have been successfully examined for their negative effects on the life parameters of some economically pest insects (Gatehouse et al., 1995; Powell, 2001; Foissac et al., 2000; Couty et al., 2001b; Sauvion et al., 2004; karimi et al., 2007; ShahidiNoghabi et al., 2008, 2009) (Table 1).
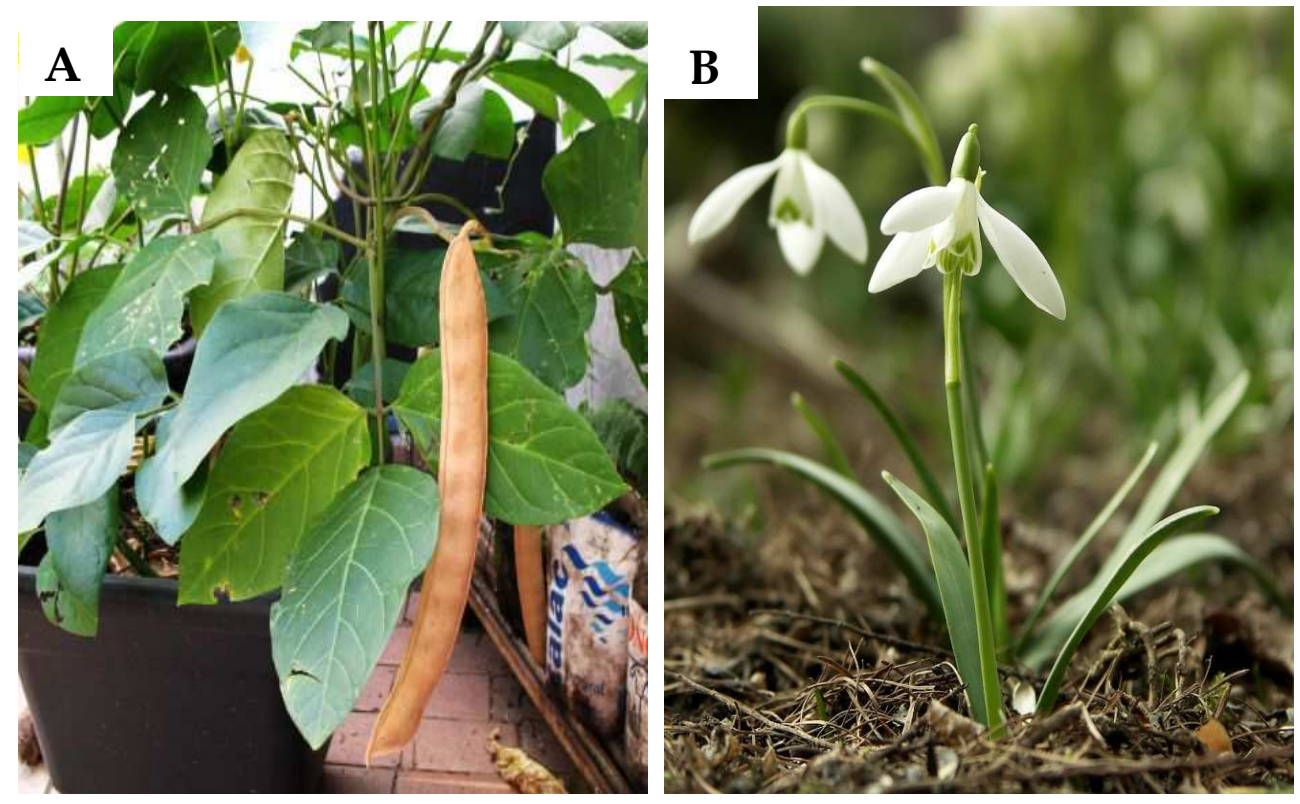

Fig. 1. (A). Canavalia ensiformis, or Jack-bean (Common name), is a legume plant in the Fabaceae family of which is used for animal fodder and human nutrition, especially in Brazil. It is also the source of concanavalin A lectin. (B) Galanthus nivalis or snowdrop (Common name), is the best-known and most widespread representative plant in the Amaryllidaceae family. (Figures from Wikipedia, (A) Canavalia ensiformis, (B) Galanthus nivalis)

Three mannose-binding specific lectins include Galanthus nivalis (GNA), Narcissus pseudonarcissus (NPA) and Allium sativum(ASA) were assayed in artificial diets for their toxic and growth-inhibitory effects on nymphal development of the peach-potato aphid, Myzus persicae. Results showed that the snowdrop lectin (GNA) was the most toxic, with an induced nymphal mortality of $42 \%$ at $1500 \mu \mathrm{g} / \mathrm{ml}$ and an median insect toxicity value $\mathrm{IC}_{50}$ (50\% growth inhibition) of $630 \mu \mathrm{g} / \mathrm{ml}$ (Fig. 1B). But daffodil lectin (NPA) and a garlic lectin (ASA) induced no significant mortality in the range of $10-1500 \mu \mathrm{g} / \mathrm{ml}$ (Sauvion et al., 1996). 
Obtained results from the effects of Canavalia ensiformis agglutinin (Con A) and Galantus nivalis agglutinin (GNA) on the developmental period and fecundity of the peach-potato aphid, Myzus persicae showed that adult survival was not significantly altered, but both lectins adversely affected total fecundity and developmental period (Sauvion et al., 1996). Later, the same assay was performed to evaluate the efficiency of Con A in pea aphid, Acyrthosiphon pisum. Results showed that Con A has highly significant toxic effects on $A$. pisum. It also induced remarkable effects on the structure of midgut epithelial cells of this aphid (Sauvion et al., 2004). These results clearly show that plants lectins play a crucial role in plant resistance against insect pests.

\section{Transgenic plants with insecticidal lectin gene}

Among plant lectins presented in table (1) as entomotoxic lectins some of which especially GNA, WGA, PSA, PHA and ConA were more successfully expressed in a range of crops such as Tomato, Rice, Sugarcane, Tobacco, Maize, Mustard and Arabidopsis (Table 1) and they have been shown to exert deleterious effects on a range of important pest insects (Maddock et al., 1991; Kanrar et al., 2002; Boulter et al., 1990c; Bell et al., 1999, 2001; Down et al., 2001 ; Maqbool et al., 2001; Sun et al., 2002; Wu et al., 2002 ; Setamou et al., 2002; Down et al., 1996; Fitches et al., 1997, 2001; Rao et al., 1998; Foissac et al., 2000). Currently, the two major groups of plant derived genes used to confer insect resistance on crops are lectins and inhibitors of digestive enzymes (proteases and amylase inhibitors). Lectins have been introduced into crops genomes and are now being tested in field conditions (Gatehouse et al., 1993; Hilder et al., 1987; Hilder et al., 1999; Carlini et al., 2002; Schuler et al., 1998; Ranjeker et al., 2003; Schnepf \& whitely, 1981; Smith \& Boyko, 2006; Christou et al., 2006; Wang, 2006; Zhao, 2006; Ferry, 2006). Also, for the first time Jjanhong et al (2003) reported that transgenic tobacco expressing Pinellia ternata agglutinin (pta) gene induced enhance level of resistance to M. persicae. Additionally, crops have been engineered to express a range of insect-plant resistance (Table 2 ), and have been shown to confer enhanced levels of resistance to different order of insect pests including lepidopteran (Gatehouse et al., 1997), and homopteran (Down et al., 1996; Gatehouse et al., 1996), when expressed in wheat. Transgenic plants technology or genetically modified (GM) crops can be a useful tool to produce resistant crops; by introducing novel resistance genes into plants thus it provides a sustainable alternative to the control of pest insects and pathogens by pesticides (Gatehouse et al., 1997; 1999; Gray et al., 2003).

On the whole, transgenic plants expressing high levels of lectins exhibited some degree of resistance to the target insects. Some of lectins such as GNA, WGA and ConA have been succefuly expressed in plants to confer resistence pest insects (Table 2) (Powell et al., 1995; Down et al., 1996; Bandyopadhyay et al., 2001).

\section{Fungal lectins with insecticidal activity}

Mushrooms contain various potential interesting proteins, including lectins in their organs such as mycelium, spores and fruiting bodies (Wang et al., 1998; 2002; Ng, 2004; Nelson \& Cox, 2005). For many years, all investigations were only focused on plant lectins with insecticidal activity. Even though lectins are found in many kinds of organisms such as fungi, but there is little information about their toxicity on phytophagus insects. Therefore, at present our knowledge about insecticidal activity of fungal lectins is limited. Due to lack of sufficient knowledge, one of the aims of this chapter is to introduce and highlight the 
fungal lectins with insecticidal activity. Recently, important progress is made in the study of the fungal lectins against pathogens, especially pest insects (karimi et al., 2007 and 2008; Hamshou et al., 2010; Francis et al., 2011). Many lectins have been derived from different fungi and partially isolated and characterized for their effects on mammalian physiology as antitumor and anticancer, but there is little information on their role on phytophagous insects (Wang et al., 2002; Trigueros et al., 2003, Karimi et al., 2008).

\begin{tabular}{|c|c|c|c|}
\hline Transformed plant & Lectina & Target pest & Reference \\
\hline Maize & WGA & $\begin{array}{l}\text { Ostrinia nubilaris; Diabrotica } \\
\text { undecimpunctata }\end{array}$ & Maddock et al., 1991 \\
\hline Mustard (B. juncea) & WGA & Lipaphis erysimi & Kanrar et al., 2002 \\
\hline Arabidopsis thaliana & PHA-E, Lb & Lacanobia oleracea & Fitches et al., 2001b \\
\hline Potato & GNA & Aulacorthum solani & Down et al., 1996 \\
\hline Potato & GNA & Myzus persicae & $\begin{array}{l}\text { Gatehouse et al., 1996; } \\
\text { Couty et al., 2001b }\end{array}$ \\
\hline Potato & GNA & L. oleracea & $\begin{array}{l}\text { Fitches et al., 1997; } \\
\text { Gatehouse et al., } 1997\end{array}$ \\
\hline Potato & GNA & L. oleracea & $\begin{array}{l}\text { Bell et al., 1999, 2001; } \\
\text { Down et al., } 2001\end{array}$ \\
\hline Potato & GNA & $\begin{array}{l}\text { Aphidius ervi (parasitoid of } M \text {. } \\
\text { persicae) }\end{array}$ & Couty et al., 2001b \\
\hline Potato & ConA & L. oleracea; M. persicae & Gatehouse et al., 1999 \\
\hline Rice & GNA & Nilaparvata lugens & $\begin{array}{l}\text { Rao et al., 1998; Foissac et } \\
\text { al., 2000; Tinjuangjun et } \\
\text { al., 2000; Maqbool et al., } \\
\text { 2001; Tang et al., 2001; Loc } \\
\text { et al., } 2002\end{array}$ \\
\hline Rice & GNA & $\begin{array}{l}\text { Nephotettix virescens (green } \\
\text { leafhopper) }\end{array}$ & Foissac et al., 2000 \\
\hline Rice & GNA & $\begin{array}{l}\text { Cnaphalocrocis medinalis (rice } \\
\text { leaffolder); Scirpophaga } \\
\text { incertulas(yellow stemborer) }\end{array}$ & Maqbool et al., 2001 \\
\hline Rice & GNA & $\begin{array}{l}\text { Laodelphax striatellus (rice small } \\
\text { brown planthopper) }\end{array}$ & $\begin{array}{l}\text { Sun et al., 2002; Wu et al., } \\
2002\end{array}$ \\
\hline Sugarcane & GNA & $\begin{array}{l}\text { Eoreuma loftini (Mexican rice borer); } \\
\text { Diatraea saccharalis (sugarcane borer) }\end{array}$ & Setamou et al., 2002 \\
\hline Sugarcane & GNA & $\begin{array}{l}\text { Parallorhogas pyralophagus (parasitoid } \\
\text { of E. loftini) }\end{array}$ & Tomov and Bernal, 2003 \\
\hline Tobacco & PSA & Heliothis virescens (tobacco budworm) & Boulter et al. 1990c \\
\hline Tobacco & GNA & M. persicae & Hilder et al., 1995 \\
\hline Tobacco & GNA & Helicoverpa zea (cotton bollworm) & Wang and Guo, 1999 \\
\hline Wheat & GNA & Sitobion avenae (grain aphid) & Stoger et al., 1999 \\
\hline
\end{tabular}

a: For lectin abbreviations see Table 1.

c: First demonstration of insect enhanced resistance of transgenic plants expressing a foreign lectin.

Table 2. Transgenic plants with lectin genes to confer resistance against insects (Adapted from Vasconcelos et al., 2004)

Some lectins from fungi including Xerocomus chrysenteron (XCL), Arthrobotrys oligospora (AOL) and Agaricus bisprous (ABL) have been isolated and all are well known for their reversible antiproliferative effects. But, only XCL has shown significant effects and exhibited a higher insecticidal activity on the some orders of insect pests, such as dipteran (Drosophila 
melanogaster) and homopteran (Myzus persicae and Acyrthosipon pisum (Trigueros et al., 2003; Karimi et al., 2008). Later, effect of this edible wild mushroom (Fig. 1) was evaluated on M. persicae aphid by Karimi et al (2008) and obtained results showed that the sub lethal dose of XCL $(<50 \mu \mathrm{g} / \mathrm{ml})$ has significant effects on biological parameters (larval weight, developmental period and fecundity) of $M$. persicae in compare with sub lethal dose of Con A $(<50 \mu \mathrm{g} / \mathrm{ml})$ on biological parameters of this aphid under laboratory conditions (Abbott, 1925; Karimi et al., 2008), (Table 3 and Fig. 3A).

Recently, the results from insecticidal properties of Sclerotinia sclerotiorum agglutinin (SSA) and its interaction with pea aphid, Acyrthosiphon pisum tissues and cells showed that this fungal lectin has high mortality on $A$. pisum with a median insect toxicity value $\left(\mathrm{IC}_{50}\right)$ of $66 \mu \mathrm{g} / \mathrm{ml}$. Also these results revealed that SSA has significant cell toxicity on A. pisum midgut tract and its brush border cells (Hamshou et al., 2010) (Fig. 2). Moreover, a purified lectin from Rhizoctonia solani agglutinin (RSA), which exhibits specificity towards $\mathrm{N}$-acetyl/galactosamine, was shown to exert deleterious effects on the growth, developmental time, survival and the larval weight of the cotton leaf worm, Spodoptera littoralis (Hamshou et al., 2010).

More recently, another new mannose- specific lectin with insecticidal activity has been successfully purified from Penicillum chrysogenum (PeCL). This lectin has high insecticidal activity on aphids, especially to $M$. persicae in comparison with well-known plant lectins, ConA. (Francis et al, 2011; karimi et al., 2006, 2007 and 2008), (Table 3 and Fig. 3B).

Consequently until now, several mushroom lectins including, Xerocomus chrysenteron lectin (XCL), Penicillum chrysogenum lectin ((PeCL) and Sclerotinia sclerotium agglutinin (SSA) have shown greater potential effects on some important pest insects such as Myzus persicae, Acyrthosipon pisum and Spodoptera littoralis compare to well known lectins such as ConA and GNA (Trigueros et al., 2003; karimi et al., 2006, 2007, 2008; Hamshou et al., 2010; Francis et al., 2011). As a result, it is concluded that fungal lectin will be able to confer enhanced level of resistance in plants against their phytophagous insects.

\section{Action mechanism of lectin at the tissue level of insects}

Investigation on the lectin toxicity at the cellular level in insects were initiated 24 years ago, when Gatehouse et al. (1984) firstly reported the binding of Phaseolus vulgaris lectin (PHA) to midgut epithelial cells of the cowpea weevil, Callosobruchus maculatus. In fact, the mode of action for each lectin at the tissue level of ingested lectin organisms is depended on presence of appropriate carbohydrate moieties on the organ surface and the ability of lectin to bind them (Fitches et al., 2001a; 2001b).

In general, the action mechanism of the lectin at cellular level of ingested lectin by insects showed that binding of the lectin to the midgut tract causing disruption of the epithelial cells including elongation of the striated border microvilli, swelling of the epithelial cells into the lumen of the gut lead to complete closure of the lumen, permeability of cell membrane to allow the harmful substances penetrations from lumen towards haemolymph and impaired nutrient assimilation by cells, allowing absorption of potentially harmful substances from lumen into circulatory system, fat bodies, ovarioles and throughout the haemolymph (Gatehouse et al., 1984; Powell et al., 1998; Habibi et al., 1998; 2000; Fitches et al., 1998; 2001b; Sauvion et al., 2004; Majumder et al., 2005). This information gave further support to previous suggestions that the XCL lectins disrupt midgut cells (Francis et al., 2003; Karimi et al., 2008, 2009). Lectins are highly specific for binding to oligosaccharides, hence if specific carbohydrate is in the surface of tissue it can bind to them and it is believed 


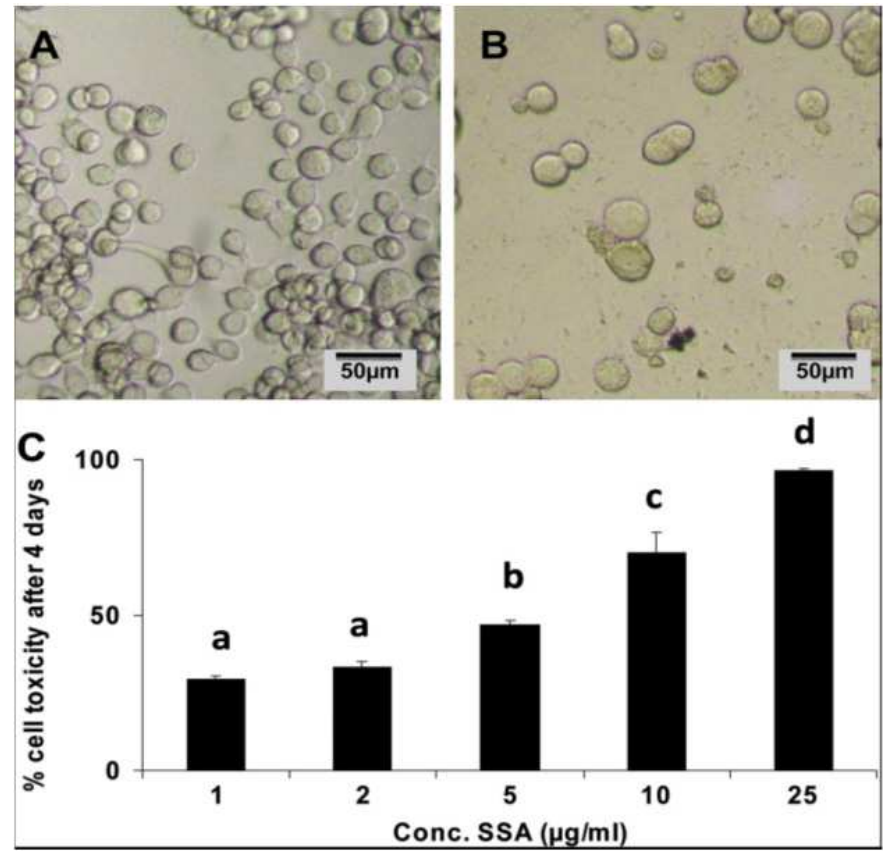

Fig. 2. Effect of different concentrations of SSA on insect midgut CF-203 cells. Cells were incubated for 4 days at $27^{\circ} \mathrm{C}$. (A) Control, (B) Treated cells with $25 \mathrm{mg} / \mathrm{ml} \mathrm{SSA}$, (C) SSA toxicity towards CF-203 midgut cells. Cell toxicity was measured using an MTT assay after 4 days of exposure to SSA at various concentrations. Data are presented as mean percentages of cell toxicity \pm SEM compared to the control, and based on four repeats and the experiments were repeated two or three times. Values with a different letter are significantly different after a post hoc Tukey Kramer test ( $\mathrm{p}^{1 / 4}$ 0.05) (Figure from Hamshou et al., 2010).

\begin{tabular}{llll}
\hline Lectin (fungal source) & \multicolumn{1}{c}{ Insect } & Host & Reference \\
\hline $\begin{array}{l}\text { N-acetyl-D-galactosamine } \\
\text { specific } \\
\text { XCL(Xerocomus chrysenteron) }\end{array}$ & $\begin{array}{l}\text { M. persicae, Acyrthosipon } \\
\text { pisum } \\
\text { Drosophila melanogaster }\end{array}$ & $\begin{array}{l}\text { Peach, potato, } \\
\text { Pea }\end{array}$ & $\begin{array}{l}\text { Trigueros, et al., } \\
2003 ; \\
\text { Karimi et al., 2008 }\end{array}$ \\
$\begin{array}{llll}\text { SSA (Sclerotinia sclerotium) } \\
\text { Acyrthosipon pisum }\end{array}$ & Pea & $\begin{array}{l}\text { Hamshou et al., } \\
2010 \mathrm{~b}\end{array}$ \\
$\begin{array}{l}\text { RSA (Rhizoctonia solani } \\
\text { agglutinin) }\end{array}$ & Spodoptera littoralis & cotton & $\begin{array}{l}\text { Hamshou et al., } \\
\text { Mannose specific }\end{array}$ \\
$\begin{array}{l}\text { PeCL(penicillum } \\
\text { chrysogenum })\end{array}$ & $\begin{array}{l}\text { M. persicae, Acyrthosipon } \\
\text { pisum }\end{array}$ & $\begin{array}{l}\text { Peach, potato, } \\
\text { Pea }\end{array}$ & $\begin{array}{l}\text { Francis et al., } \\
2011\end{array}$ \\
\hline
\end{tabular}

Table 3. Fungal lectins with insecticidal activity (Karimi et al., 2011) 

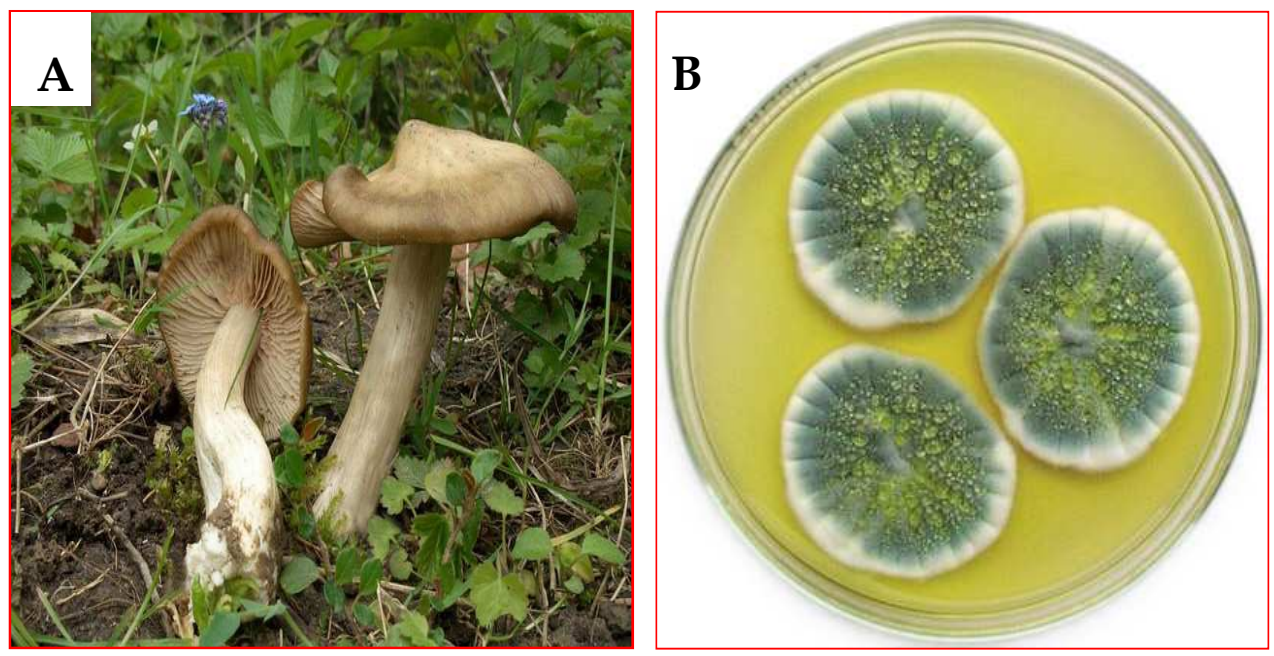

Fig. 3. (A) Xercomus chrysenteron fungus naturally growth in forest. It is a small, edible wild mushroom in the Boletaceae family and has a cosmopolitan distribution, concentrated in cool-temperate to subtropical regions. (B) Penicillums chrysogenum fungus growth in medium culture. It can be found on salted food products as well as indoor environments, especially in damp or water damaged buildings. This fungus is in the Tricocomaceae family. To date is used as anti bacterial disease. (Figures from Wikipedia, (A) Xercomus chrysenteron,

(B) Penicillums chrysogenum)

that these cell-surface receptors are responsible for lectin binding. Thus, it could be concluded that the action mechanism of various lectins at the cellular levels of insects differs between different insect species (Habibi et al., 2000; Fitches et al., 2001a; Sauvion et al., 2004; Karimi et al., 2009). Consequently, the action mechanism of the lectin at the cellular level of insect are not clearly elucidated yet and the information is scarce.

\section{Indirect effects of lectins on pests control}

In some case lectin have an indirect remarkable effects; such as interaction with virus transmission and synergistic effects on the other proteins.

\subsection{Interaction with virus transmission}

In general some of insects such as aphids transmit virus from infected plant to non infected plants. Some lectins such as mannose-binding lectins are able to bind to carbohydrate on micro-organisms. Circulatory viruses contain numerous $\mathrm{N}$-linked glycosylation sites on their surface cells. Many of these sites contain high-mannose glycans which could interact with mannose-binding lectin such as ConA (Gray et al., 1999; Brisson and Stern, 2006; Hogenhout et al., 2008; Desoignies, 2008; Thielens et al., 2002; Pereira et al., 2008; Naidu et al., 2004; Dimitrov, 2004; Garret et al., 1993; Wei, 2007). 


\subsection{Synergistic effects on other proteins}

Sometimes the combinations effects of two or several entomotoxic proteins could be more efficient than the application of these proteins individually. For example, the insecticidal activity of protease inhibitor and a-amilase inhibitors were significantly increased when these inhibitors enzymes incorporated with lectin (Abdeen et al., 2005; Amirhusin et al., 2004; Murdock \& Shade, 2002). Maqbool et al. (2001) reported that rice transgenic plant carrying three insecticidal genes including lectin gene (encoding gene GNA), cry1A and cry 2A, have enhanced levels of resistance to a wide range of different rice pests in comparison with non transgenic rice. Therefore, this approach will be one of the supplemented advantages to lectin applications in integrated pest management (IPM).

\section{Conclusion}

The aim of the current chapter was to present up to date information regarding effects of the lectins especially introducing the fungal lectins as natural agents to control insect pests. In recent years due to increasing the harmful effects of chemical compounds on non target organisms and our environment, a safe alternative to this approach is inevitable. Actually, lectins could be alternatives to chemical compounds for the pests control. Results from different investigations were shown that plant lectins as well as fungal lectins could be good candidates to be applied in the agriculture by biotechnologist in order to control insect pest.

\section{Acknowledgement}

The authors would like to acknowledge Iran National Science Foundation (INSF) for their financial support. This work was funded by a grant (No. 86025.11) from INSF.

\section{References}

Abbott W. S., 1925. A method of computing the effectiveness of an insecticide.J. Econ. Entomol., 18, 265-267.

Abdeen A., Virgos A., Olivella E., Villanueva J., Aviles X., Gabarra R \& Prat S., 2005. Multiple insect resistance in transgenic tomato plants over- expressing two families of plant proteinase inhibitors. Plant Mol. Biol., 57, 189-202.

Allsopp P. G. \& McGhie T. K., 1996. Snowdrop and wheat germ lectins as antimetabolites for the control of sugarcane white grubs. Entomol. Exp. Appl., 80(2), 409-414.

Amirhusin B., Shade R. E., Koiwa H., Hasegawa P.M., Bressan R.A., Murdock L. L., ZhuSalzman K., 2004. Soyacystatin N inhibits proteolysis of wheat alpha-amylase inhibitor and potentiates toxicity against cowpea weevil. J. Econ. Entomol., 97, 20952100.

Amirhusin B., Shade R. E., Koiwa H., Hasegawa P. M., Bressan R. A., Murdock L. L \& ZhuSalzman K., 2007. Protease inhibitors from several classes work synergistically against Callosobruchus maculatus. J. insect physiol., 53(7), 734-740.

Aronson A. I., 1994. Bacillus thuringiensis and its use as a biological insecticide. In: Janick J., ed. Plant Breeding Reviews. New York, USA, Wiley., pp, 19-45. 
Bandyopadhyay S., Roy A. \& Das S., 2001. Binding of garlic (Allium sativum) leaf lectin to the gut receptors of homopteran pests is correlated to its insecticidal activity.Plant Sci., 61(5), 1025-1033.

Baldwin I. T., Sims C. L. \& Kean S. E., 1990. The reproductive consequences associated with inducible alkaloid responses in wild tobacco. Ecology., 71, 252-62.

Bell H. A., Fitches E. C., Down R. E., Marris G. C., Edwards J. P., Gatehouse J. A. \& Gatehouse A. M. R., 1999. The effect of snowdrop lectin (GNA) delivered via artificial diet and transgenic plants on Eulophus pennicornis (Hymenoptera: Eulophidae) a parasitoid of the tomato moth Lacanobia oleracea (Lepidoptera: Noctuidae). J. Insect Physiol., 45(11), 983-991.

Bell H. A., Fitches E. C., Down R. E., Ford L., Marris G.C., Edwards J. P., Gatehouse J.A., Gatehouse A.M. R., 2001. Effect of dietary cowpea trypsin inhibitor (CpTI) on the growth and development of the tomato moth, Lacanobia oleracea (Lepidoptera: Noctuidae) and on the success of the gregarious ectoparasitoid, Eulophus pennicornis (Hymenoptera: Eulophidae). Pest Manage. Sci., 57(1), 57-65.

Bell H. A., Kirkbride-Smith A. E., Marris G. C., Edwards J. P. \& Gatehouse A. M. R., 2004. Oral toxicity and impact on fecundity of three insecticidal proteins on the gregarious ectoparasitoid Eulophus pennicornis (Hymenoptera: Eulophidae). Agric. Forest Entomol., 6(3), 215-222.

Boulter D., Edwards G. A., Gatehouse A. M. R., Gatehouse J. A. \& Hilder V. A., 1990. Additive protective effects of incorporating two different higher plants derived insect resistance genes in transgenic tobacco plants. Crop Prot., 9(5), 351-354.

Brisson, J. A., Stern, D. L., 2006. The pea aphid, Acyrthosiphon pisum: an emerging genomic model system for ecological, developmental and evolutionary studies. Bioessays., 28, 747-755.

Carlini C. R. \& Grossi-de-Sa M. F., 2002. Plant toxic proteins with insecticidal properties: a review on their potentialities as bio-insecticides. Toxicon., 40(11), 1515-1539.

Chandra N. R., Kumar N, Jeyakani J., Singh D. D., Sharan B. Gowda S. B. \& Prathima M. N., 2006. Lectindb: a plant lectin database. Glycobiology., 16(10), 938-946.

Chrispeels M. J. \& Raikhel N. V., 1991. Lectins, lectin genes, and their role in plant defense. Plant Cell., 3, 1-9.

Christou P., Capell T., Kohli A., Gatehouse J. A \& Gatehouse A. M. R., 2006. Recent developments and future prospects in insect pest control in transgenic crops. Trends Plant Sci., 11, 302-308.

Cole R. A., 1994. Isolation of a chitin-binding lectin with insecticidal activity in chemicallydefined synthetic diets from two wild Brassica species with resistance to cabbage aphid Brevicoryne brassicae. Entomol. Exp. Appl., 72, 181-187.

Conner A. J., Glare T. R. \& Nap J. P., 2003. The release of genetically modified crops into the environment-Part II. Overview of ecological risk assessment. Plant J., 33(1), 19-46.

Couty A., Down R. E., Gatehouse A. M. R., Kaiser L., Pham-Delegue M.H. \& Poppy G. M., 2001. Effects of artificial diet containing GNA and GNA-expressing potatoes on the development of the aphid parasitoid, Aphidius ervi Haliday (Hymenoptera: Aphidiidae). J. Insect Physiol., 47(12), 1357-1366. 
Czapla T. H. \& Lang B. A., 1990. Effect of plant lectins on the larval development of European corn borer (Lepidoptera: Pyralidae) and southern corn rootworm (Coleoptera: Crysomelidae). J. Econ. Entomol., 83, 2480-2485.

Desoignies N., 2008. Étude des interactions virus-vecteur:transmission par Myzus persicae d'un virus sur le mode non-persistant (PVY) et d'un virus sur le mode persistant (PLRV). Mémoire DEA : Université Catholique de Louvain (Belgique).

Dimitrov D. S., 2004. Virus entry: molecular mechanisms and biomedical applications. Nat. Rev. Microbiol., 2(2), 109-122.

Dixon H. B. F., 1981. Defining a lectin. Letter to Nature. Nature, 292(1981), 192.

Down R. E., Gatehouse A. M. R., Hamilton W. D. O. \& Gatehouse J. A., 1996. Snowdrop lectin inhibits development and decreases fecundity of the glasshouse potato aphid (Aulacorthum solani) when administered in vitro and via transgenic plants both in laboratory and glasshouse trial. J. Insect Physiol., 42(11), 1035-1045.

Down R. E., Ford L., Bedford S. J., Gatehouse L. N., Newell C., Gatehouse J. A. \& Gatehouse A. M. R., 2001. Influence of plant development and environment on transgene expression in potato and consequences for insect resistance. Transgenic Res., 10, 223 236.

Elden T. C., 2000. Influence of a cysteine proteinase inhibitor on alfafa weevil (Coleptera: Curculionidae) growth and development over successive generations. J. Entomol.Sci., 35, 70-76.

Etzler M. E., 1986. Distribution and function of plant lectins. In: Liener I.E., Sharon N. \& Goldstein I. J., eds. The lectins. San Diego, CA, USA: Academic Press., 371-435.

Ferre J. \& Rie J. V., 2002. Biochemistry and genetics of insect resistance to Bacillus thuringiensis. Ann. Rev. Entomol., 47, 501-533.

Ferry N., Edwards M. G., Gatehouse T., Capell P., Christou P. \& Gatehouse A. M. R., 2006.

Transgenic plants for insect pest control: a forward looking scientific perspective. Transgenic Res., 15, 13-19.

Fitches E., Gatehouse A. M. R. \& Gatehouse J. A., 1997. Effects of snowdrop lectin (GNA) delivered via artificial diet and transgenic plant on the development of tomato moth (Lacanobia oleracea) larvae in laboratory and glasshouse trials. J. Insect Physiol., 43(8), 727-739.

Fitches E. \& Gatehouse J. A., 1998. A comparison of the short and long term effects of insecticidal lectins on the activities of soluble and brush border enzymes of tomato moth larvae (Laconobia oleracea). J. Insect Physiol., 44(12), 1213-1224.

Fitches E., Woodhouse S. D., Edwards J. P. \& Gatehouse J. A., 2001a. In vitro and in vivo binding of snowdrop (Galanthus nivalis agglutinin; GNA) and jackbean (Canavalia ensiformis; ConA) lectins within tomato moth (Lacanobia oleracea) larvae; mechanisms of insecticidal action. J. Insect Physiol., 47(7), 777-787.

Fitches E., Ilett C., Gatehouse A. M. R., Gatehouse L. N., Greene R., Edwards J. P. \& Gatehouse J. A., 2001b. The effects of Phaseolus vulgaris erythro- and leucoagglutinating isolectins (PHA-E and PHA-L) delivered via artificial diet and transgenic plants on the growth and development of tomato moth (Lacanobia oleracea) larvae; lectin binding to gut glycoproteins in vitro and in vivo. J. Insect Physiol., 47(12), 1389-1398. 
Foissac X., Loc N.T., Christou P., Gatehouse A. M. R. \& Gatehouse J. A., 2000. Resistance to green leafhopper (Nephotettix virescens) and brown planthopper (Nilaparvata lugens) in transgenic rice expressing snowdrop lectin (Galanthus nivalis agglutinin; GNA). J. Insect Physiol., 46(4), 573-583.

Francis F., Marty-Detraves C., Poincloux R., Baricault L., Fournier D. \& Paquereau L., 2003. Fungal lectin, XCL, is internalized via clathrin-dependent endocytosis and facilitates uptake of other molecules. Eur. J. Cell Biol., 82(10), 515-522.

Francis F., Karimi J., Colinet F., Daniel Portetele D and Haubruge E., 2011. Purification of a new fungal mannose-specific lectin from Penicillium chrysogenum and its aphicidal properties.

Fungal biology., 115, 1093-1099.

Garret A., Kerlan C. \& Thomas D., 1993. The intestine is a site of passage for potato leafroll virus from the gut lumen into the haemocoel in the aphid vector, Myzus persicae Sulz. Arch. Virol., 131(3), 377-392.

Gatehouse A. M. R., Dewey F. M., Dove J., Fenton K. A. \& Pusztai A., 1984. Effect of seed lectins from Phaseolus vulgaris on the development of larvae of Callosobruchus maculatus; mechanism of toxicity. J. Sci. Food Agric., 35(4), 373-380.

Gatehouse A. M. R., Barbieri L., Stirpe F. \& Croy R. R. D., 1990. Effects of ribosome inactivating proteins on insect development-differences between Lepidoptera and Coleoptera. Entomol. Exp. Appl., 54(1), 43-51.

Gatehouse A. M. R., Howe D. S., Flemming J. E., Hilder V. A., Gatehouse J. A., 1991a. Biochemical basis of insect resistance in winged bean (Psophocarpus tetragonolobus) seeds. J. Sci. Food Agric., 55, 63-74.

Gatehouse, J. A., Hilder, V. A. \& Gatehouse, A. M. R. 1991b. Genetic engineering of plants for insect resistance. In Plant Genetic Engineering, Plant Biotechnology Series, V ol. 1, ed. D. Grierson. Blackie \& Sons Ltd, London/Chapman and Hall, New York, pp. 105-35.

Gatehouse A. M. R., Shi Y., Powell K. S., Brough C., Hilder V. A., Hamilton W. D. O., Newell, C. A., Merryweather A., Boulter D. \& Gatehouse J. A., 1993. Approaches to insect resistance using transgenic plants. Philos. Trans. R. Soc. London. Biol. Sci., 342(1301), 279-286.

Gatehouse A. M. R., Powell K. S., Peumans W. J., Van Damme E. J. M. \& Gatehouse J. A., 1995. Insecticidal properties of plant lectins: their potential in plant protection. In: Pusztai A. \& Bardocz S., eds. Lectins: biomedical perspectives. London: Taylor \& Francis., 35-58.

Gatehouse A. M. R., Down R. E., Powell K. S., Sauvion N., Rahbé Y., Newell C. A., Merryweather A. \& Hamilton W. D. O., Gatehouse J. A., 1996. Transgenic potato plants with enhanced resistance to the peach-potato aphid, Mizus persicae. Entomol. Exp. Appl., 79(3), 295-307.

Gatehouse A. M. R., Davison G. M., Newell C. A., Hamilton W. D. O., Burgess E. P. J., Gilbert, R. J. C. \& Gatehouse J. A., 1997. Transgenic potato plants with enhanced resistance to the tomato moth, Lacanobia oleracea: growth room trials. Mol. Breed., 3(1), 49-63. 
Gatehouse A. M. R. \& Gatehouse J. A., 1998. Identifying proteins with insecticidal activity: use of encoding genes to produce insect-resistant transgenic crops. Pest Sci., 52(2), 165-175.

Gatehouse A. M. R, Davison G. M., Stewart J. N., Galehouse L. N., Kumar A., Geoghegan I. E., Birch A. N. E. \& Gatehouse J. A., 1999. Concanavalin A inhibits development of tomato moth (Lacanobia oleracea) and peach-potato aphid (Myzus persicae) when expressed in transgenic potato plants. Mol. Breed., 5(2), 153-165.

Gildow F. E., 1993. The aphid salivary gland basal lamina as a selective barrier associated with vector-specific transmission of barley yellow dwarf luteoviruses. Phytopathology., 83(12), 1293-1302.

Goldstein I. J. \& Poretz R. D., 1986. Isolation, physicochemical characterization, and carbohydrate-binding specificity of lectins. In: Liener I.E., Sharon N. \& Goldstein I. J., eds. The lectins. Orlando, FL, USA: Academic Press., 33-247.

Gray S. M., 1996. Plant virus proteins involved in natural vector transmission. Trends Microbiol., 4(7), 259-264.

Gray S. M. \& Banerjee N., 1999. Mechanisms of arthropod transmission of plant and animal viruses. Microbiol. Mol. Biol. Rev., 63(1), 128-148.

Gray S. M. \& Gildow F. E., 2003. Luteovirus-aphid interactions. Annu. Rev. Phytopathol., 41, 539-566.

Gurjar M. M., Gaikwad S. M., Haila Salokhe S. G, Mukherjee S \& Islamkhan M., 2000. Growth inhibition and total loss of reproductive potential in Tribolium castaneum by Artocarpus hirsut lectin. Invertebr. Reprod. Dev., 38, 95-98.

Habibi J. E., Backus E. A. \& Czapla T. M., 1993. Plant lectins affect survival of the potato leafhopper (Homoptera: Cicadellidae). J. Econ. Entomol., 86(3), 945-951.

Habibi J. E., Backus E. A. \& Czapla T. H., 1998. Subcellular effects and localization of binding sites of phytohemagglutinin in the potato leafhopper, Empoasca fabae (Insecta: Homoptera: Cicadellidae). Cell Tissue Res., 294(3), 561-571.

Habibi J. E., Backus E. A. \& Huesing J. E., 2000. Effects of phytohemagglutinin (PHA) on the structure of midgut epithelial cells and localization of its binding sites in western tarnished plant bug Lygus hesperus Knight. J. Insect Physiol., 46(5), 611-619.

Halitschke R., Schittko U., Pohnert G., Boland W. \& Baldwin I.T., 2001. Molecular interactions between the specialist herbivore Manduca sexta (Lepidoptera, Sphingidae) and its natural host Nicotiana attenuata. III. Fatty acid-amino acid conjugates in herbivore oral secretions are necessary and sufficient for herbivorespecific plant responses. Plant Physiol., 125(4), 711-717.

Hamshou M, Smagghe G., Shahidi-Noghabi S., De Geyter E., Lannoo N., Van Damme EJM., 2010. Insecticidal properties of Sclerotinia sclerotiorum agglutinin and its interaction with insect tissues and cells. Insect Biochem. and Molecul. Biol.,40, 883-890.

Hamshou M., Smagghe G., Van Damme E. J. M., 2010. Entomotoxic effects of fungal lectin fromRhizoctonia solani towards Spodoptera littoralis. Fungal Biol., 114, 34-40.

Hilder V. A., Gatehouse A. M. R., Sherman S. E., Baler R. F. \& Boulter D., 1987. A novel mechanism for insect resistance engineered into tobacco. Nature., 330, 160-163.

Hilder V. A., Powell K. S., Gatehouse A. M. R., Gatehouse J. A., Gatehouse L. N., Shi Y., Hamilton W. D. O., Merryweather A., Newell C. A., Timans J. C., Peumans W. J., 
Van Damme E.J.M. \& Boulter D., 1995. Expression of snowdrop lectin in transgenic tobacco results in added protection against aphids. Transgenic Res., 4(1), 18-25.

Hilder V.A. \& Boulter D., 1999. Genetic engineering of crop plants for insect resistance: a critical review. Crop Prot., 18(3), 177-191.

Hogenhout S. A., Ammar E. D., Whitfield A. E. \& Redinbaugh M.G., 2008. Insect vector interactions with persistently transmitted viruses. Ann. Rev. Phytopathol., 46, 327359.

Janmaat A. F. \& Myers J., 2003. Rapid evolution and the cost of resistance to Bacillus thuringiensis in greenhouse populations of cabbage loopers, Trichoplusia ni. Proc. $R$. Soc. London Ser. Biol. Sci., 270, 2263-2270.

Yao J., Pang Y., Qi H., Wan B., Zhao X., Kong W., Sun X., Tang K., 2003.Transgenic Tobacco Expressing Pinellia ternata Agglutinin Confers Enhanced Resistance to Aphids. Transgenic Res., 12(6), 715-22.

Jongsma M. A. \& Bolter C., 1997. The adaptation of insects to plant protease inhibitors. J. Insect Physiol., 43, 885- 895.

Kanrar S., Venkateswari J., Kirti P. B. \& Chopra V. L., 2002. Transgenic Indian mustard (Brassica juncea) with resistance to the mustard aphid (Lipaphis erysimi Kalt.). Plant Cell Rep., 20, 976-981.

Karimi J., Paquereau L., Fournier D., Haubruge E. \& Francis F., 2006. Use of artificial diet system to assess the potential bio-insecticide effect of a fungal lectin from Xerocomus chrysenteron (XCL) on Myzus persicae. Comm. Appl. Biol. Sci. Ghent Univ., 71(2b), 497-505.

Karimi J., Paquereau L., Fournier D., Haubruge E. \& Francis F., 2007. Effect of a fungal lectin from Xerocomus chrysenteron (XCL) on the biological parameters of Myzus persicae. Comm. Appl. Biol. Sci. Ghent Univ., 72(3), 629-638.

Karimi j., 2009. Study of fungal lectins as potential bio-pesticides to control aphid pests. Ph.D. thesis. Agricualtural University of Gembloux, Belgium. 124pp.

Karimi J., Francis F., Cuartero Diaz G., Haubruge E., 2008. Investigation of Carbohydrate binding property of a fungal lectin from Xerocomus chrysenteron and potential use on Myzus persicae aphid. Ghent University (in press). Comm. in Agricul. and Appl. Biol. Sci.., 73/3,629-938.

Karimi J., Francis F., Haubruge E., 2010. Development of entomotoxic molecules as control agents: illustration of some protein potential uses and limits of lectins. Biotech., Agro., Société et Environ., 14(1), 225-241.

Kumar M. A., Timm D. E., Neet K. E., Owen W. G., Peumans W. J. \& Rao A. G., 1993. Characterization of the lectin from the bulbs of Eranthis hyemalis (winter aconite) as an inhibitor of protein synthesis. J. Biol. Chem., 268(33), 25176-25183.

Leple J. C., Bonade-bottino M., Agustin S., Pilate G., Dumanois Lê Tân V., Deplanque A., Coru D. \& Jouanin L., 1995. Toxicity to Chrysomela tremulae (Coleoptera: Crysomelidae) of transgenic poplars expressing a cysteine proteinase inhibitor. Mol. Breed., 1, 319-328.

Lis H. \& Sharon N., 1998. Lectins: carbohydrate-specific proteins that mediate cellular recognition. Chem. Rev., 98, 637-674. 
Loc N. T., Tinjuangjun P., Gatehouse A. M. R., Christou P. \& Gatehouse J. A., 2002. Linear transgene constructs lacking vector backbone sequences generate transgenic rice plants which accumulate higher levels of proteins conferring insect resistance against a range of different rice pest. Mol. Breed., 9, 231-244.

Ma Q. H., Tian B., Li Y. L., 2010. Overexpression of a wheat jasmonate-regulated lectin increases pathogen resistance. Biochimie., 92, 187-193.

Macedo M. L. R., Freire M. G. M., Novello J. C. \& Marangoni S., 2002. Talisia esculenta lectin and larval development of Callosobruchus maculatus and Zabrotes subfasciatus (Coleoptera: Bruchidae). Biochim. Biophys.Acta., 1571, 83-88.

Macedo M. L. R., Damico D. C., Freire M. G. M., Toyama M. H., Marangoni S. \& Novello J.C., 2003. Purification and characterization of an N-acetylglucosamine-binding lectin from Koelreuteria paniculata seeds and its effect on the larval development of Callosobruchus maculatus (Coleoptera: Bruchidae) and Anagasta kuehniella (Lepidoptera: Pyralidae). J. Agric. Food Chem., 51, 2980-2986.

Macedo M. L. R., Freire M. G. M., Silva M. B. R. \& Coelho L.C. B. B., 2006. Insecticidal action of Bauhinia monandra leaf lectin (BmoLL) against Anagasta kuehniella (Lepidoptera: Pyralidae), Zabrotes subfasciatus and Callosobruchus maculatus (Coleoptera: Bruchidae). Comp. Biochem. Physiol., 146, 486-498.

Machuka J., Van Damme E. J. M., Peumans W. J. \& Jackai L. E. N., 1999. Effect of plant lectins on survival development of the pod borer Maruca vitrata. Entomol.Exp. Appl., 93, 179-187.

Machuka J. S., Okeola O. G., Chrispeels M. J. \& Jackai L. E. N., 2000. The African yam bean seed lectin affects the development of the cowpea weevil but does not affect the development of larvae of the legume pod borer. Phytochemistry., 53, 667-674.

Maddock S. E., Hufman G., Isenhour D. J., Roth B. A., Raikhel N. V., Howard J. A. \& Czapla T. H., 1991. Expression in maize plants of wheat germ agglutinin, a novel source of insect resistance. In: Third International Congress in Plant Molecular Biology, Tucson, Arizona, USA.

Majumder P., Mondal H. A. \& Das S., 2005. Insecticidal activity of Arum maculatum tuber lectin and its binding to the glycosylated insect gut receptors. J. Agric. Food Chem., 53(17), 6725-6729.

Maqbool S. B., Riazuddin S., Loc N. T., Gatehouse A. M. R., Gatehouse J. A. \& Christou P., 2001. Expression of multiple insecticidal genes confers broad resistance against a range of different rice pests. Mol. Breed., 7, 85-93.

Marsh M. \& Helenius A., 2006. Virus entry: open sesame. Cell, 124(4), 729-740.

McGaughey W. H. \& Whalon M. E., 1992. Managing insect resistance to Bacillus thuringiensis toxins. Science., 258, 1451-1455.

Murdock L. L. \& Shade R. E., 2002. Lectins and protease inhibitors as plant defense against insects. J. Agric. Food Chem., 50(22), 6605-6611.

Naidu R. A., Ingle C. J., Deom C. M. \& Sherwood J. L., 2004. The two envelope membrane glycoproteins of tomato spotted wilt virus show differences in lectin-binding properties and sensitivities to glycosidases. Virology., 319, 107-117.

Nelson D. \& Cox M., 2005. Lehninger principles of biochemistry. 4th ed. Freeman. Ng T.B., 2004. Peptides and proteins from fungi. Peptides., 25(6), 1055-1073. 
Ng T. B., Chan W. Y. \& Yeung H. W., 1992. Proteins with abortifacient, ribosome inactivating, immunomodulatory, antitumor and anti-AIDS activities from Cucurbitaceae plants. Gen. Pharmacol., 23(4), 575-590.

Okeola O. G. \& Machuka J., 2001. Biological effects of African yam bean lectins on Clavigralla tomentosicollis (Hemiptera: Coreidae). J. Econ. Entomol., 94, 724-729.

Peumans W. J. \& Van Damme E. J. M., 1995. Lectins as plant defense proteins. Plant Physiol., 109(2), 347-352.

Peumans W. J., Hao Q. \& Van Damme E. J. M., 2001. Ribosome-inactivating proteins from plants: more than RNA N-glycosidases. FASEB J., 15(9), 1493-1506.

Powell K. S., 2001. Antimetabolic effects of plant lectins towards nymphal stages of the planthoppers Tarophagous proserpina and Nilaparvata lugens. Entomol. Exp. Appl., 99(1), 71-77.

Powell K. S., Gatehouse A. M. R., Hilder V. A. \& Gatehouse J. A., 1993. Antimetabolic effects of plants lectins and fungal enzymes on the nymphal stages of two important rice pests, Nilaparvata lugens and Nephotettix cinciteps. Entomol. Exp. Appl., 66(2), 119-126.

Powell K. S., Gatehouse A. M. R., Hilder V. A., Van Damme E. J. M., Peumans W. J., Boonjawat J., Horsham K. \& Gatehouse J. A., 1995. Different antimetabolic effects of related lectins towards nymphal stages of Nilaparvata lugens. Entomol. Exp. Appl., 75(1), 61-65.

Powell K. S., Spence J., Bharathi M., Gatehouse J. A. \& Gatehouse A. M. R., 1998. Immunohistochemical and developmental studies to elucidate the mechanism of action of the snowdrop lectin on the rice brown planthopper Nilaparvata lugens (Stal). J. Insect Physiol., 44(7), 529-539.

Rahbé Y. \& Febvay G., 1993. Protein toxicity to aphid: an in vitro test on Acyrthosiphon pisum. Entomol. Exp. Appl., 67(2), 149-160.

Rahbe' Y., Sauvion N., Febvay G., Peumans W. J. \& Gatehouse A. M. R., 1995. Toxicity of lectins and processing of ingested proteins in the pea aphid Acyrthosiphon pisum. Entomol. Exp. Appl., 76, 143-155.

Rahbé Y., Deraison C., Bonadé-Bottino M., Girard C., Nardon C., Jouanin L., 2003. Effects of the cysteine protease inhibitor oryzacystatin (OC-I) on different aphids and reduced performance of Myzus persicae on OC-I expression transgenic oilseed rape. Plant Sci., 164(4), 441-450.

Rahbé Y., Ferrasson E., Rabesona H. \& Quillien L., 2003b. Toxicity to the pea aphid Acyrthosiphon pisum of antichymotrypsin isoforms and fragments of Bowman-Birk protease inhibitors from pea seeds. Insect Biochem. Mol. Biol., 33, 299-306.

Ranjekar P. K., Patankar A., Gupta V., Bhatnagar R., Bentur J. \& Kumar P. A., 2003. Genetic engineering of crop plants for insect resistance. Curr. Sci., 84, 321-329.

Rao K.V., Rathore K. S., Hodges T. K., Fu X., Stoger E., Sudhakar D., Williams S., Christou P., Bharathi M., Bown D. P., Powell K. S., Spence J., Gatehouse A. M. R. \& Gatehouse J. A., 1998. Expression of snowdrop lectin (GNA) in transgenic rice plants confers resistance to rice brown planthopper. Plant J., 15(4), 469-477.

Roy A., Banerjee S., Majumder P. \& Das S., 2002. Efficiency of mannose-binding plant lectins in controlling a homopteran insect, the red cotton bug. J. Agric. Food Chem., 50, 6775-6779. 
Rudiger H. \& Gabius H. J., 2001. Plant lectins: occurrence, biochemistry, functions and applications. Glycoconjugate J., 18(8), 589-613.

Sauvion N., Rahbe Y., Peumans W. J., Van Damme E. J. M., Gatehouse J. A. \& Gatehouse A. M. R., 1996. Effects of GNA and other mannose binding lectins on development and fecundity of the potato-peach aphid Myzus persicae. Entomol. Exp.Appl., 79, 285293.

Sauvion N., Nardon C., Febvay G., Angharad M., Gatehouse R. \& Rahbe Y., 2004. Binding of the insecticidal lectin Concanavalin A in pea aphid, Acyrthosiphon pisum (Harris) and induced effects on the structure of midgut epithelial cells. J. Insect Physiol., 50(12), 1137-1150.

Schnepf H. E. \& Whiteley H. R., 1981. Cloning and expression of the Bacillus thuringiensis crystal protein gene in Escherichia coli. Proc. Natl Acad. Sci. USA, 78(5), 2893-2897.

Schuler T. H., Poppy G. M., Kerry B. R. \& Denholm I., 1998. Insect resistant transgenic plants. Trends Biotechnol., 16, 168-175.

Scott J. G. \& Wen Z. M., 2001. Cytochromes P450 of insects: the tip of the iceberg. Pest Manage. Sci., 57(10), 958-967.

Setamou M., Bernal J. S., Legaspi J. C., Mirkov T. E. \& Legaspi B. C., 2002. Evaluation of lectin-expressing transgenic sugarcane against stalkborers (Lepidoptera: Pyralidae): effects on life history parameters. J. Econ. Entomol., 95(2), 469-477.

Shahidi-Noghabi S., Van Damme E. J. M. \& Smagghe G., 2008. Carbohydrate-binding activity of the type-2 ribosome-inactivating protein SNA-I from elderberry (Sambucus nigra) is a determining factor for its insecticidal activity. Phytochemistry., 69(17), 2972-2978.

Shahidi-Noghabi S., Van Damme E. J. M. \& Smagghe G., 2009. Expression of Sambucus nigra agglutinin (SNAI0) from elderberry bark in transgenic tobacco plants results in enhanced resistance to different insect species. Transgenic Res., 18, 249-259.

Smith C. M. \& Boyko L. V., 2006. The molecular bases of plant resistance and defense responses to aphid feeding: current status. Entomol. Exp. Appl., 122(1), 1-16.

Stillmark H., 1888. Ueber Ricin, ein giftiges Ferment aus dem Samen von Ricinus communis L. und einigen anderen Euphorbiaceen. Arb. Pharmak. Inst. Dorpat., 3, 59-151.

Stirpe F. \& Battelli M.G., 2006. Ribosome-inactivating proteins: progress and problems. Cell Mol. Life Sci., 63(16), 1850-1866.

Stoger E., Williams S., Christou P., Down R. E. \& Gatehouse J. A., 1999. Expression of the insecticidal lectin from snowdrop (Galanthus nivalis agglutinin, GNA) in transgenic wheat plants: effects predation by the grain aphids Sitobion avenae. Mol. Breed., 5(1), 65-73.

Sun X., Wu A. \& Tang K., 2002. Transgenic rice lines with enhanced resistance to the small brown planthopper. Crop Prot., 21(6), 511-514.

Tabashnik B. E., Cushing N. L., Finson N. \& Johnson M. W., 1990. Field development of resistance to Bacillus thuringiensis in diamondback moth (Lepidoptera: Plutellidae). J. Econ. Entomol., 83, 1671-1676.

Tang K., Zhao E., Sun X., Wan B., Qi H. \& Lu X., 2001. Production of transgenic rice homozygous lines with enhanced resistance to the rice brown planthopper. Acta. Biotechnol., 21, 117-128. 
Thielens N. M., Tacnet-Delorme E. P. \& Arlaud G. J., 2002. Interaction of C1q and mannanbinding lectin with viruses. Immunobiology., 205, 563-574.

Tinjuangjun P., Loc N. T., Gatehouse A. M. R., Gatehouse J. A. \& Christou P., 2000. Enhanced insect resistance in Thai rice varieties generated by particle bombardment. Mol. Breed., 6, 391-399.

Tomov B. W. \& Bernal J. S., 2003. Effects of GNA transgenic sugarcane on life history parameters of Parallorhogas pyralophagus (Marsh) (Hymenoptera: Braconidae), a parasitoid of Mexican rice borer. J. Econ. Entomol., 96, 570-576.

Trigueros V., Lougarre A., Ali-Ahmed D., Rahbe Y., Guillot J., Chavant L., Fournier D. \& Paquereau L., 2003. Xerocomus chrysenteron lectin: identification of a new pesticidal protein. Entomol. Exp. Appl., 1621(3), 292-298.

Van Damme E. J. M., Peumans W. J., Pusztai A. \& Bardocz S., 1998. Handbook of plant lectins: properties and biomedical applications. Bognor Regis, UK: John Wiley and Sons.

Vasconcelos I. M. \& Oliveira J. T. A., 2004. Antinutritional properties of plant lectins. Toxicon., 44(4), 385-403.

Wang G., Zhang J., Song F., Wu J., Feng S. \& Huang D., 2006. Engineered Bacillus thuringiensis G033A with broad insecticidal activity against lepidopteran and coleopteran pests. Appl. Microbiol.Biotechnol., 72(5), 924-930.

Wang H., Ng T. B. \& Liu Q., 2003. A novel lectin from the wild mushroom Polyporus adusta. Biochem. Biophys. Res. Commun., 307, 535-539.

Wang H. X, Ng T. B. \& Ooi V. E. C., 1998. Lectins from mushroom. Mycol. Res., 102, 897-906.

Wang M., Trigueros V., Paquereau L., Chavant L. \& Fournier D., 2002. Proteins as active compounds involved in insecticidal activity of mushroom fruitbodies. $J$. Econ.Entomol., 95, 603-617.

Wang Z. B. \& Guo S. D., 1999. Expression of two insect resistant genes cryIA (bandc) GNA in transgenic tobacco plants results in added protection against both cotton bollworm and aphids. Chin. Sci. Bull., 44, 2051-2058.

Wei T., Chen H., Ichiki-Uehara T., Hibino H. \& Omura T., 2007. Entry of rice dwarf virus into cultured cells of its insect vector involves clathrin-mediated endocytosis. J. Virol., 81(14), 7811-7815.

Wu A., Sun X., Pang Y. \& Tang K., 2002. Homozygous transgenic rice lines expressing GNA with enhanced resistance to the rice sap-sucking pest Laodelphax striatellus. Plant Breed., 121, 93-95.

Yamada T., Hattori K. \& Ishimoto M., 2001. Purification and characterization of two $\square-$ amylase inhibitors from seeds of tepary bean (Phaseolus acutifolius A.gray). Phytochemistry., 58(1), 59-66.

Zhao J. Z., Cao J., Li Y. X., Collins H. L., Roush R.T., Earle E. D., Shelton A. M., 2003. Transgenic plants expressing two Bacillus thuringiensis toxins delay insect resistance evolution. Nat. Biotechnology., 21, 1493-1497.

Zhu K., Joseph E. H., Richard E. S., Ray A. B., Paul M. H., Larry L. M., 1996. An insecticidal $\mathrm{N}$-acetylglucosamine specific lectin gene from Griffonia simplicifolia (Leguminosae). Plant Physiol., 110, 195-202.

Zhu-Salzman K., Shade R.E., Koiwa H., Salzman R.A., Narasimhan M., Bressan, R.A., Hasegawa P.M. \& Murdock L.L., 1998. Carbohydrate binding and resistance to 
proteolysis control insecticidal activity of Griffonia simplicifolia lectin II. Proc. Natl Acad. Sci.USA., 95, 15123-15128.

Zhu-Salzman K. \& Salzman R., 2001. A functional mechanic of the plant defensive Griffonia simplicifolia lectin II: resistance to proteolysis is independent of glycoconjugate binding in the insect gut. J. Econ. Entomol., 94, 1280-1284. 


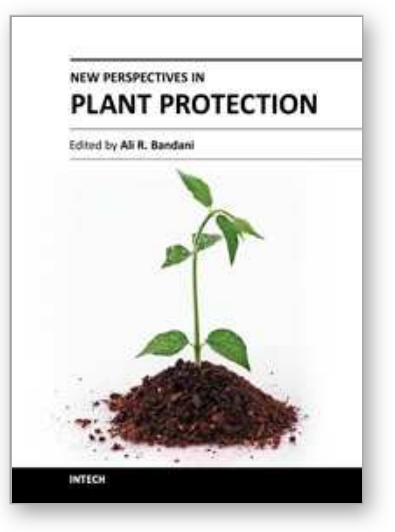

\author{
New Perspectives in Plant Protection \\ Edited by Prof. Ali R. Bandani
}

ISBN 978-953-51-0490-2

Hard cover, 246 pages

Publisher InTech

Published online 11, April, 2012

Published in print edition April, 2012

Crop losses by pests (insects, diseases and weeds) are as old as plant themselves but as agriculture are intensified and cropping patterns including the cultivation of high yielding varieties and hybrids are changing over time the impact of the pests becoming increasingly important. Approximately less than 1000 insect species (roughly 600-800 species), $1500-2000$ plant species, numerous fungal, bacterial and nematode species as well as viruses are considered serious pests in agriculture. If these pests were not properly controlled, crop yields and their quality would drop, considerably. In addition production costs as well as food and fiber prices are increased. The current book is going to put Plant Protection approaches in perspective.

\title{
How to reference
}

In order to correctly reference this scholarly work, feel free to copy and paste the following:

J. Karimi, M. Allahyari and A. R. Bandani (2012). Lectins and Their Roles in Pests Control, New Perspectives in Plant Protection, Prof. Ali R. Bandani (Ed.), ISBN: 978-953-51-0490-2, InTech, Available from:

http://www.intechopen.com/books/new-perspectives-in-plant-protection/lectins-and-their-roles-in-pest-control

\section{INTECH}

open science | open minds

\section{InTech Europe}

University Campus STeP Ri

Slavka Krautzeka 83/A

51000 Rijeka, Croatia

Phone: +385 (51) 770447

Fax: +385 (51) 686166

www.intechopen.com

\section{InTech China}

Unit 405, Office Block, Hotel Equatorial Shanghai

No.65, Yan An Road (West), Shanghai, 200040, China

中国上海市延安西路65号上海国际贵都大饭店办公楼 405 单元

Phone: +86-21-62489820

Fax: +86-21-62489821 
(C) 2012 The Author(s). Licensee IntechOpen. This is an open access article distributed under the terms of the Creative Commons Attribution 3.0 License, which permits unrestricted use, distribution, and reproduction in any medium, provided the original work is properly cited. 